\title{
CHALLENGES FOR HUMAN RESOURCES MANAGEMENT FOCUSED ON THE RECRUITMENT, EDUCATION AND REMUNERATION OF EMPLOYEES IN POST-CRISIS PERIOD
}

\author{
Petra Janečková, Radim Řihák
}

\section{Klíčová slova:}

Human Resources Management, podnik, trend, získávání a výběr zaměstnanců, vzdělávání, zaměstnanecká výhoda

\section{Key words:}

Human Resources Management, enterprise, trend, recruitment and selection of employees, education, employee benefit

\begin{abstract}
Abstrakt
Tento př́spěvek pojednává o problematice Human Resources Management v návaznosti na hospodářskou krizi. Cúlem článku je poukázat na klíčové postavení personálního managementu v po-krizovém období s důrazem na nastupující nové trendy v oblasti Human Resources a perspektivy jejich vývoje. V souvislosti $\mathrm{s}$ děním vevropských zemích a očekávaným př́íchodem další krize vymezují autoři pro účely tohoto příspěvku po-krizové období v České republice počátkem roku 2010 až koncem 3. čtvrtletí roku 2011. V příspěvku naznačené a v praxi již mnohdy započaté trendy v oblasti Human Resources Management budou vlivem další krize patrně zpomaleny či utlumeny. Po jejím ústupu v nich však budou mnohé podniky dále pokračovat.

Výzva budoucnosti voblasti Human Resources může pro mnoho podniků spočívat ve využívání moderních přístupů v Human Resources Management. Moderní přístupy mohou taktéž přispět ke snížení fluktuace nejen klíčových a talentovaných zaměstnancủ podniku. Jedná se např́klad o způsoby získávání a výběru pracovníků; průběžné plánování nástupnictví; vyšší využití potenciálu vlastních zaměstnanců; uvědomělá, efektivní a přitom nákladově zvládnutelná péče o pracovníky a jejich vzdělávání; stejně tak racionální orientace na benefitní odměňování pracovníků. Trendům v uvedených oblastech Human Resources Management je věnován tento příspěvek.
\end{abstract}

\begin{abstract}
This paper discusses the issues of HRM in relation to the economic crisis. The aim of the paper to highlight the key role of personnel management in post-crisis period with an emphasis on emerging new trends in HR and perspectives of their development. For the purposes of this paper and in connection with events in European countries and the expected arrival of another crisis, the authors define the post-crisis period in the Czech Republic from early 2010 to the end of the 3rd quarter of 2011. These trends of HRM outlined in this paper, which in many cases have been put into practice, will probably be slowed or inhibited by the next crisis. Nevertheless, many companies will continue in these trends after the retreat of the crisis.

The use of modern approaches in corporate HRM can become a strong competitive advantage of companies. These approaches may help to reduce fluctuations of the key and talented employees. These include the methods of recruiting; ongoing succession planning; high potential of internal employees; conscious, effective, yet cost-manageable care for workers and their education; as well as rational focus on remuneration. This paper is devoted to such trends in the area of HRM.
\end{abstract}




\section{Introduction}

The global economic crisis affected almost all areas of human activity. The period of its duration and also the following quarters after its subsides (the period of retreat of economic crisis in the Czech business sphere starts in 2010, more significantly in its second half) are closely linked to the development on the labour market. The impact of the economic downturn has direct influence on the unemployment rate in each sector and undoubtedly affects the personnel policy of many companies. At the end of 2010, the International Labour Organization (ILO) stated that "the global unemployment will not reach the level before the crisis earlier than in the year 2015."1 Since the beginning of the crisis, around 30 to 35 million jobs have disappeared in the world. Reducing the number of employees, which occurred in many companies especially in the years 2008 and 2009, has resulted, among other, in positive changes in employees' approach to their work. In many cases, and not only because of the fears of loosing their jobs, employees' work performance increased. In the post-crisis period, defined above, we can trace gradual finding of employees' lost confidence as well as their courage and readiness to change their current not that convenient but stable job for better-rated ones in the labour market. We need to bear in mind that a company can achieve a significant competitive advantage already by its approach to its job applicants in the admission process, by targeted work with its key staff and last but not least, by its actual setting of evaluation, remuneration and employee training systems - particularly by their efficiency and transparency. Low employees' loyalty to their company is often the result of improper adjustment of the mutual working relationship employee - employer. Staff turnover is one of the biggest pitfalls in the working process and it gets severe when employees have the same or similar reasons for the termination of employment and subsequent departure from the company. In this context, the level of mutual internal communication plays a large role. Especially companies' HR departments must, by their measures and above all by their considered personnel policy, prevent these problems and reduce the level of employee turnover as much as possible. From this perspective, the position and the equivalent status of the HR department with other departments of an enterprise is very important. HR departments are increasingly called upon to participate in steering the organization through changes that appear as a result of new trends in globalization, technology, labour markets, but also in financial perspective. All this was even compounded by the lingering economic crisis in 2010. Landa considers the future role of HR in business strategies, the position of HR departments within a company and indicates several strategic approaches for the future. This is mainly a "shift to leadership, innovation initiative, teamwork, managing changes via projects, effective cooperation using the potential of Internet technologies. "2 And how Hroník adds, "people's performance is determined not only by their competence, but also by their attitude. ${ }^{\prime 3}$ It is the attitude that is crucial in the environment of ever-increasing competitiveness. Further existence of enterprises and their positions in the markets will depend mainly on the degree of successful application of strategic HR approaches and on the identification with the emerging global trends.

The scientific research activities of the authors of this article (the students of doctoral studies) were supported by Moravian-Silesian Region within the support of science and research. This paper discusses the issues of HRM in relation to the economic crisis. Its purpose is to

\footnotetext{
${ }^{1}$ ILO: Zaměstnanost vzroste až v roce 2015. HRM - Human Resources Management, November - December 2010, p. 9.

${ }^{2}$ LANDA, O. Jakou roli ve strategii dnes hraje HR? HRM - Human Resources Management, May - June 2010, p. 14.

${ }^{3}$ HRONÍK, F. Změna role HR aneb řízení lidí v pohybu. HRM - Human Resources Management, May - June 2010, p. 18.
} 
summarise the impact of the crisis, and to predict major trends in corporate Human Resources Management in post-crisis period. The post-crisis period, discussed in this paper in the connection with HRM, has to be time-bounded with regard to developments in European countries in recent months because it is evident that the crisis is coming back. The authors define the period from the beginning of 2010 to the end of the 3rd quarter of $2011^{4}$. In relation to the post-crisis period, this paper relates entirely to these time boundaries. The current economic situation in Europe may limit or for a few months delay developments in the field of HRM (outlined in the paper), but it is clear that the described development trends will again continue after the retreat of the crisis.

\section{Challenges for HR in Planning and Filling Job Positions}

During the period of economic crisis, there were many changes in the area of HR planning in terms of its narrower definition, i.e. ensuring a certain number of workers with appropriate qualifications. Enterprises had to adapt to them and still have to do so in the post-crisis period. During the toughest period of ever decreasing demand for their production, many companies were forced to reduce the costs of human resources, choose less costly methods of HR activities, or even dismiss their employees. This period often negatively affected almost all HR activities in the enterprises. Although the majority of these changes (HR measures) had adverse effects on behaviour, actions, relationships and the loyalty of employees, the situation on the labour market (especially problems with finding a new job) prevented the voluntary departures of employees from companies, so-called "voluntary" turnover of employees. Unemployment was therefore mainly increased by the dismissal of employees. In the process of subsequent gradual economic stabilization, which is still ongoing and threatened by the events in some European countries (mainly due to their indebtedness), the question for each company is how to deal with the negative impact of the crisis. Thus, whether the post-crisis period becomes a challenge or the opportunity to learn from the crisis and step in the right direction, or it does not. The following text indicates some of the trends or already initiated processes in HR activities.

In the area of recruitment, we can say that this period was beneficial for those companies that have managed to overcome the difficult period of economic crisis and learn from it. Many companies have learned to make better use of its human resources and by appropriate motivational tools, they head for increasing the productivity of skilled workers. Less capable, less productive employees are usually dismissed from the company. This fact can be also considered to be entirely rational in terms of efficiency and effectiveness of resource (in this case, human resources) and thus, of finding ways to increase employee and corporate performance. More efficient use of human resources has a direct impact on recruiting the approaches to recruitment have changed. Job positions, that were necessary to be filled after the retreat of the economic crisis, were primarily filled from the internal resources of companies. Companies have started to monitor and evaluate the performance of their employees, created succession plans and employee career development plans, which allows them to know better their internal resources of employees, by whom the jobs are filled. Job positions that can not be filled from their own resources were filled by candidates from

\footnotetext{
${ }^{4}$ This period can be characterized by beginnings ganges in the HRM area, reflecting the positive progress of the GDP indicator as compared to 2008 and 2009. Regarding the companies' management, the focus and interest is being brought back to personel actions and HR processes of the company. A chapter in HEČKO, Š., MACHÁČKOVÁ, P., ŘIHÁK, R. The Impact of Economic Crisis on Human Resources Management. In NENIČKA, L., ŞIRINER, I. Globalisation Dimensions \& Impacts. London: IJOPEC Publication, 2011, s. 112 135. ISBN 978-0956825629 focuses on the area of HRM during the extensive recession in 2008 and 2009.
} 
external sources - and even here noticeable changes occurred in the post-crisis period. Due to the monitoring the costs of filling a job position, i.e. recruiting and training of an employee, companies streamline the approaches to these activities. During the retreat of the economic crisis, companies were forced to choose workers with clearly defined skills and experiences. "When companies recruited new employees, they searched for candidates that absolutely met their requirements. ${ }^{15}$ Such an approach is not surprising, however, it did not produce too much of a positive effect on the decline in unemployment (especially in the unemployment of graduates) in the labour market. In this costly activity, companies were forced to choose certainty. Still, this approach to recruiting can not be considered all-solving and completely correct in the long term. The lesson for companies in choosing the selection of methods and more precise specification of requirements for candidates for a job position, it is necessary to target the wider range of future employees who will be then trained and developed. Therefore, the recruitment can not be limited (the recruitment from external sources) only to candidates who are able to take the job almost immediately. In the last phase of the economic crisis, the recruiting process was, for financial reasons, often transferred from employment agencies to companies' HR departments. This fact is also emphasized by Přikryl - "in recent years, the recruitment has been significantly transferred to companies' HR departments. " ${ }^{\prime 6}$ The benefit of this post-crisis measure was the streamlining of the recruitment activities in HR departments (if appropriate methods were used). In connection with this change, however, Prikryl adds that the provision of recruitment by HR departments has its limitations. A small number of vacancies could be thus filled, but with increased demand for employees it could lead to the overloading of HR departments and to the decrease of the quality of their work not only in this HR activity. This problem obviously applies to larger companies. From these considerations (that in future, companies will not be able to provide greater number of workers by themselves and therefore, will have to use the services of recruitment agencies again), another benefit of the economic crisis can be concluded. Another benefit (in case of cooperation with recruitment agencies) will be companies' more precise approach in laying the requirements for the job candidates. By this, the frequently mentioned disadvantage of recruitment via recruitment agencies could be largely eliminated or even completely removed. This disadvantage is emphasized by Koubek: "In cases where the co-leaders of organizations are less involved in recruiting, there is the danger of finding and accepting not entirely suitable workers (the problem of insufficient information flow between the intermediary and the organization, excessive reliance on the intermediary institution). ${ }^{7}$ The list of possible directions is obviously not complete but it can be an inspiration for companies seeking a "better" future.

We can say that organizations, that have implemented (or soon will implement) changes in HR processes, have learned to make better use of its human resources, established the systems of succession and career plans, started to choose workers preferably from their own employees and streamlined the recruitment from external sources, heading in the right direction toward long-term productivity and prosperity.

\section{Trends in Education and Employee Development}

The economic crisis impacted the field of HR of most companies. For the managements of

\footnotetext{
5 PŘIKRYL, J. Firmy postupují při náboru stále opatrně a jsou důkladnější. HRM - Human Resources Management, January - February 2011, p. 60.

${ }^{6}$ PŘIKRYL, J. Firmy postupují při náboru stále opatrně a jsou důkladnější. HRM - Human Resources Management, January - February 2011, p. 61.

${ }^{7}$ KOUBEK, J. Řizení lidských zdrojů. Základy moderní personalistiky. 2001, p. 132.
} 
these companies, the period, in which they were more or less forced to reduce the investment in training and staff development, began. Financial resources and budgets of HR departments were reduced and in some companies, it was a drop by half compared with the previous years. HR professionals had to adapt to a new situation, which caused the decrease in the range of training programs and activities. Those companies that successfully survived the economic crisis undoubtedly realized that their current plans for education and human resource development cannot remain unchanged in the future. It is necessary to make rational adjustments, primarily based on experience from pre-crisis and crisis periods. These plans are a very dynamic element and it is necessary, that HR departments develop it and work with it constantly. Mainly because they must reflect all external aspects of the market (the economic and demographic development of society, the legislative conditions, technological invention in the field of business) and the internal conditions of the company (quality and quantity of human capital, specific requirements of a job, organizational composition of HR departments, etc.).

The process of educating employees and the development of human capital and its potential, is essential for the future economic development and growth of a company. Staff training is the driving force that "pushes" companies into the possibility of increasing their performance and enhancing market competitiveness and overall prosperity. This process must be continuous, systematical, and it must reflect a strategic approach. "Learning and development strategy represents the approach an organization adopts to ensure that now and in the future, learning and development activities support the achievement of its goals by developing the skills and capacities of individuals and teams. ${ }^{\prime \prime}$ It is necessary to put into context and links the needs of a company and its already defined objectives within a defined business strategy and the needs of specific workers who provide key processes and activities within the company.

Thus, what is the current situation and what will the future situation be like in the field of HRM? Can we track and predict trends in education and staff development that emerged in connection to the economic crisis? In post-crisis period, personnel HR managers primarily tend to improve the educational programs in the field of staff training and development rather than reducing them. HR managers keep looking for the optimal relationship between quality and costs unlike in the pre-crisis period, when the tendency was more focused on the quantity of various educational activities. According to the authors of this article, it can be assumed that quality will dominate also in the future.

In the period affected by the crisis, it is important, during the identification of training needs, to determine the gap between current knowledge, skills, abilities of employees and the requirement for their level, as shown in the following Fig. 1. Training needs analysis itself is quite complex and challenging, but eventually, appropriately defined and specified learning gap creates the possibility how to save free capital in the time of reduction of financial resources and then invest it appropriately. The question remains, which educational program or activity would possibly be the best to address and overcome the learning gap. It is necessary to consider and accurately define still missing and by the analysis identified specific skills, abilities, knowledge that an employee has to acquire and adopt; or to determine what new job situation or behaviour is to be learned. It is necessary to mention and highlight the co-operation of HR departments with team leaders, supervisors and senior managers, because it is them who significantly enter the whole learning process.

\footnotetext{
${ }^{8}$ ARMSTRONG, M. Armstrong's Handbook of Human Resource Management Practice. 2009, p. 654.
} 
Fig. 1: The learning gap

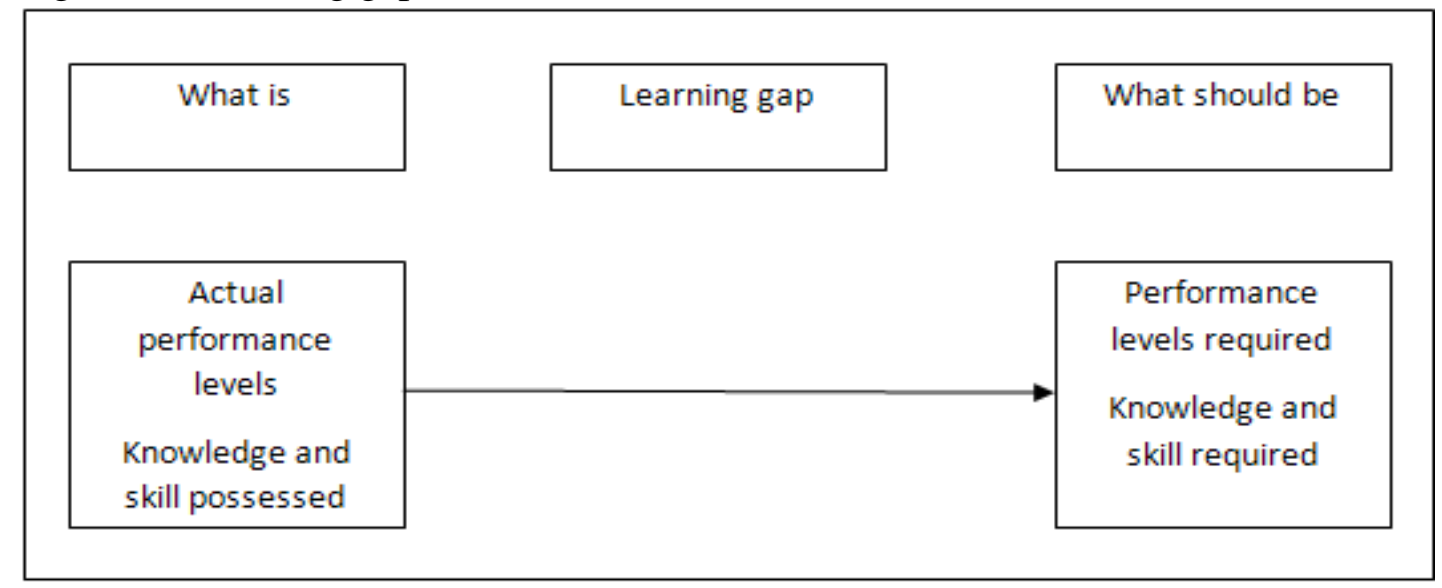

Source: ARMSTRONG, M. Armstrong's Handbook of Human Resource Management Practice, 2009, p. 690.

Although the word measurable is sometimes very difficult to grasp in the field of HR, in corporate training, it is necessary to provide the management of companies with appropriate data which demonstrate the contribution of the investment in education. According to the project Benchmarking of corporate educational systems, which was implemented in late 2010 by GE Money Bank in collaboration with the company top vision, more than a half of respondents, "in a longer period of time (min. 6 weeks or more) after completing the training does not control whether the knowledge obtained in the training was incorporated into practice. ${ }^{\prime \prime}$ From a variety of professional studies it is evident that the trend of measuring the contribution of corporate training has become increasingly necessary and essential.

Among the trends in education and employee development there also belongs also the CrossTraining or the Development of Multiskilling. As Čapková and Skalková stated: "Education as the system begins to focus on building and developing the knowledge and skills that can be used at several positions, so-called multiskilling (successfully used e.g. in Toyota). This trend is based on the principle that a position is not synonymous with an employee. If the position is abolished, the employee can be quickly and efficiently transferred to another. ${ }^{\prime 10}$ Eventually, multiskilling can thus have a positive effect also on the labour market, of course with taking into account the particular economic sector or location in which the company operates. So a worker, who would be dismissed from a company due to the cancellation of his/her position, is smoothly transferred to another one. The introduction of cross-training can lead to increased efficiency, overall effectiveness and business competitiveness on both domestic and foreign markets. At time, which changed the approach of HR departments to development strategies and staff training, Cross-Training can be viewed as one of the starting points to save time and money while maintaining the same or similar levels of companies' performance. The authors of the article think, this trend cannot be fully adopted as universal but with consideration of various sectors and job positions.

Due to the economic crisis, many people were lately forced to change their jobs or accept a job outside the field in which they had studied. The Project of the National Qualifications Framework seems to be the right step in the right direction. This project, prepared by the Ministry of Education, Youth and Sports of the Czech Republic in cooperation with

\footnotetext{
${ }^{9}$ SLABÁ, P. Všechno, co jste chtěli vědět o firemnich systémech vzděláváni a báli jste se zeptat... [online], [cit. 2011-07-25].

${ }^{10}$ ČAPKOVÁ, A., SKALKOVÁ, J. Vybrané nejnovějši trendy ve vzděláváni a rozvoji zaměstnanců. [online], [cit. 2011-07-30].
} 
the National Institute for Vocational Training is to help with some problems occurring in the labour market, e.g. the shortage of skilled workers in certain fields or professions. It allows people (after an examination) to gain a nationally recognized certificate for many years of experience, professional knowledge and experience within the industry in which they did not study.

"There will be an obvious shift from learning organizations to knowledge-based companies and organizations. ${ }^{\prime 11}$ As Hroník mentioned, a sophisticated knowledge management system allows the company to discover and exploit the knowledge inside the company and then share it among the company's employees or, according to the authors of this article, among subsidiaries and branches of the parent company or in companies with foreign participation. This modern concept of management will be deepened and used preferably also in the following period.

It can be predicted that, among the educational methods, more and more emphasis will be put on self-study. Employees themselves should take the responsibility for their professional and personal development. This is related also to the principle of lifelong learning, which will remain to be promoted in adult education. The development of various technologies, which will enter into the activities of HR departments, creates an opportunity to use these new and modern technologies also in staff training in a form of virtual courses. "In a virtual course, there is a greater concentration of knowledge; it allows returning to individual information and knowledge." ${ }^{12}$ Concepts such as training video program, e-learning, b-learning and webinar well known among the professionals. However, the question arises, whether they will be a sufficient challenge for HR departments and HR managers to be used in the educational programs.

Just-in-time is another trend in staff training. It is training at the right time to react to the current situation within the company and in its vicinity. Sending employees to courses and training on the fly is already distant past. Nowadays, a new approach gets to the forefront. It prefers the choice of such educational activities that are linked to the market situation and also reflect the internal conditions in companies. "As it is evident from the name, this form of education is characterized by flexibility and speed, i.e. employees are offered workshops in the workplace, which mostly last from 20 minutes to 2 hours - as needed."13

\section{Trends in the Remuneration of Employees}

In many cases, the impact of the economic crisis, that struck the whole world in the previous quarters, caused substantial changes also in companies' evaluation and employee remuneration processes. Dismal economic outcomes of many enterprises started, among other, a serious discussion on evaluation systems and the remuneration of employees in coming years, and especially, on how to set up the systems for the future and adapt them to new priorities and limited budgets. This corresponds, as Palata stated, to remuneration processes orientation from the "Best Practice" to "Best Fit" approach and to the establishment of a new trend in this area. He mentions: "The period before the crisis, I would call the "Best Practice" or standardization period. Companies' remuneration systems were being adapted to the latest trends and it was considered a success, when a remuneration system was in

\footnotetext{
${ }^{11}$ JEMALA, L. Souřadnice rozvoje managementu. Moderni ř́zení, May 2010, p. 52.

${ }^{12}$ KAZDOVÁ, A. Časy se mění: Více muziky za méně peněz. HRM - Human Resources Management, November - December 2010, p. 4.

${ }^{13}$ ČAPKOVÁ, A., SKALKOVÁ, J., cit 9, [cit. 2011-07-30].
} 
accordance with what the best companies were doing. However, the question was, whether the money invested in wages, indeed led to useful results; or whether the remuneration system was clear and based on good values and principles. ${ }^{14}$ It is possible to argue, how much the remuneration alienated from its substance in the past, because it has been heard, even from employees themselves, that their performance has no great influence on the reward they get. The new approach - Best Fit - can be characterized as the linking and the conformity of remuneration systems with companies' values and also as an emphasis on compliance with the fundamental principles of employee remuneration. It is thus not as much about the technical perfection of the system or about the fact whether a company remunerates an employee of a certain position in the same level as its competitors. The main purpose of this approach is the transparency of "how much the investment in wages leads to useful results, and how much it supports company's business strategy and corporate culture"15. This expected approach, however, does not mean the absolute deviation from the Best Practice approach, and thus the potential deviation from the "comparison with competitors". However, the priority of a company's remuneration philosophy will not be "to adapt", but "to customize." This new approach of certain experimenting will certainly require a perceptive approach of companies' top managements and an individual approach in setting the systems of each company. This implementation can be more difficult in multinational companies because they are currently tied up by the "global rules" thanks to their operating in many demographically and also culturally different countries or continents. On the other hand, the new approach offers the possibility of significant competitive advantage in the field of remuneration and at the same time a "fertile ground" for building positive image of employers and thus having positive effect on the loyalty of their employees.

Fig. 2: The relationship between ,the Best Practise” and „Best Fit“"

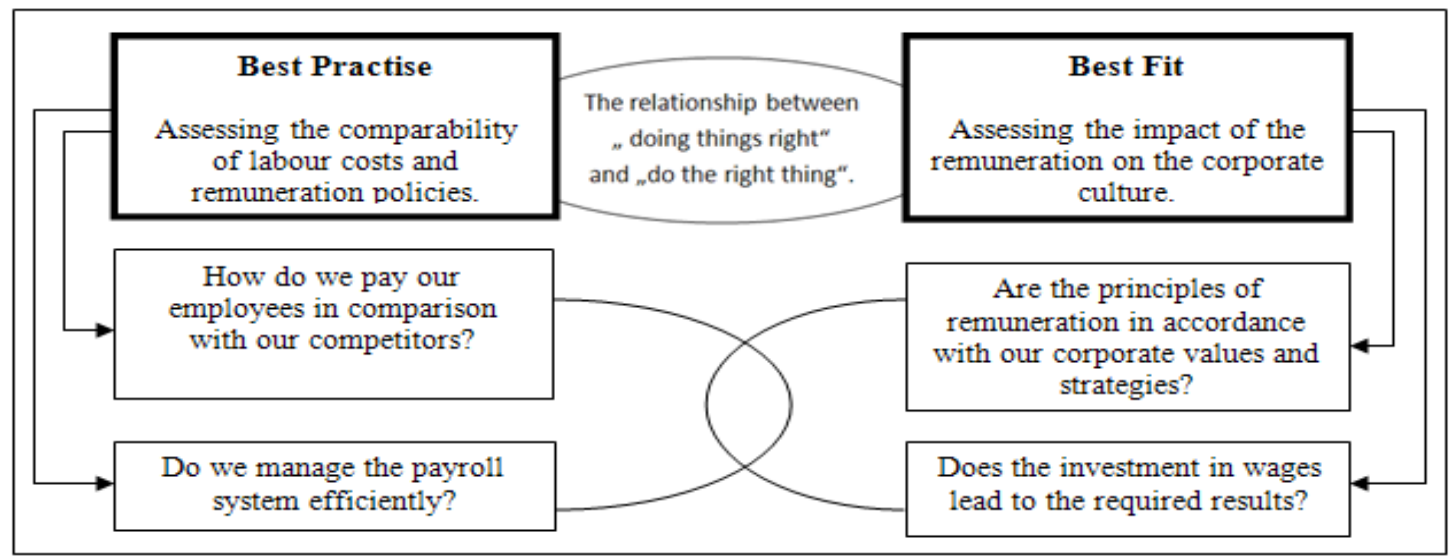

Source: PALATA, K. Trendy v odměňování. HRM - Human Resources Management, March - April 2011, p. 13.

Transparency and the Emphasis on Long-term Performance of Top Managers. This trend is a response to the current situation in many companies and to not-so-distant past when the performance of top managers were monitored preferably for rather a short period - defined by quarter to a maximum of a year. From this preferred short period of time, the enterprises unfolded remuneration systems, which also favored to some extent just shortterm success instead of rewarding success in longer term. In the future, we can expect great discussions about the setting of correct criteria for evaluation and remuneration. At the same time, there will be an emphasis put on the transparency of the system and on a company's long-term performance and its successful operation on the market. As Palata stated "delaying

\footnotetext{
${ }^{14}$ PALATA, K. Trendy v odměňování. HRM - Human Resources Management, March - April 2011, p. 14.

${ }^{15}$ PALATA, K. Trendy v odměňování. HRM - Human Resources Management, March - April 2011, p. 13.
} 
payments of bonuses, the possibility of withdrawal of paid rewards, forced dividing of bonuses to cash payments and shares should serve to these purposes. ${ }^{16}$ It is a matter of time, when this approach also extends to lower management positions and fits into the awareness of a larger number of employees. It is understandable, that a company's long-term performance is linked to the performance of top management and also to the performance of the managers in lower positions. Thus their involvement is also required. This, of course, results in an effort of top management to obtain support from their subordinates to achieve their desired success. That is why it is important to motivate the members of the middle and lower management by the application of new wage programs focused on long-term success. Phenomenon, which is linked to this trend is, that there will be a big debate about how big the ratio of the variable component of wage will be represented in the total pay. Thus the fact, what percentage of managers' salaries will be related to the "long-term success of the enterprises". And also, according to Palata, "we can expect the extension of long-term incentive programs to a larger group of workers (Long Term Incentives). " 17

Another of the trends in remuneration is a form of special awards. The authors of this article conclude that in companies, the identification with this trend will have a good response, general interest and also a positive impact on increasing employee motivation. Awarding an employee (the publication of his/her name and award-winning success) - thus the appreciation of his/her work in front of other workers - is the right way of increasing employee motivation, their loyalty and strengthening the relationship employees - employer. This trend and many others may have significant impact on reducing employee turnover in a particular company, an influence on improving mutual working relationships and last but not least, affect on the achievement of stated business objectives, thus the presumption of a successful operation on the market.

In the following period, an emphasis will be put on the transparency and maximum flexibility of the systems of remuneration. Many companies, due to the economic crisis, reduced a number of employees in the personnel area and thus saved significant financial resources. However, it would not be rational, if the aim in the field of remuneration of these companies would be only the further saving of financial resources. The constant threat of competition and the constant battle for qualified workforce should be always kept on mind. It is very important to be aware of the fact that free labour - a large number of unemployed - is in general the possible potential of companies, but not always does it mean a qualified workforce. Further reduction of resources in the area of remuneration (including reckless implementation of reduction of employee benefits) could have further far-reaching future implications associated with the termination of employment of many key and qualified employees, higher staff turnover and with that related expenditure of funds while recruiting new workers for the enterprise. The costs of placing new employees into the working process are often several times higher then the amount saved by the reduction in remuneration of current employees.

The priority of each company should therefore be to ensure an effective functioning reward system that is transparent and equitable within each department of the company and understandable for both, the employees and the managers. It can also be expected that the employees as well as the employers will be required to understand the essence and principles of remuneration systems. In many companies, the remuneration systems lose their attractiveness, efficiency and incentives. This happens due to the continuous adjustments of

\footnotetext{
${ }^{16}$ PALATA, K. Trendy v odměňování. HRM - Human Resources Management, March - April 2011, p. 14.

${ }^{17}$ PALATA, K. Trendy v odměňování. HRM - Human Resources Management, March - April 2011, p. 14.
} 
the systems, their innovation and new legislative acts. Above all, evaluation and remuneration systems, including the benefit remuneration, require mutual precise and open communication. A subsequent feedback (reaction to a change) is indispensable for the working relationship employer - employee.

In the field of benefit remuneration of employees and its trends it can be assumed that the increasing emphasis on corporate culture and the effort to achieve a positive perception of employers by their employees support the offer of benefits - the experiential benefits (e.g. parachute jump, family day in a salt cave, weekend wellness programs), benefits provided by the nature of the business activities of an employer (e.g. a bank will provide a free account and better interest rates on loans to its employees, etc.). The possibility to "buy and hold shares" of the company in which an employee works is a great motivation. At the forefront and popular among employees may still be material benefits company cars for their own use, home office for selected employees, etc.). Some other interesting benefits are "the daily intake of fruits and vegetables for each employee", possible absence at work - so-called "sick day".

It is possible to predict greater representation of some flexible forms of employee benefits (e.g. cafeteria system or other for the enterprise appropriate combinations based on flexible provision of benefits). In remuneration systems, consistent communication between employers and employees is of great importance. It is necessary to explain the principles of drawing the benefits and the requirements and the wishes of employees must not be neglected. Therefore, it is advisable to monitor the development of employee preferences at regular intervals. The portfolio of employee benefits will certainly reflect the development of the population demographic curve in the following years and therefore it will be formed by the needs of a rapidly aging society. Employees will often face the question, how to take care of aging parents and still keep their jobs. We can therefore expect a great response and interest in the possibility of working from home or part-time. Interest in these forms of work (greater flexibility) can grow among older workers or young employees with small children. Some companies have already started to focus on Generation Y in the proposals of benefits. This Generation Y is characteristic by preferring a balance between work and personal life (work-life balance).

Not only is the competition the cause for increasing pressure on the job performance of employees. Such pressure is certainly negatively reflected on personal lives of employees, their relationships and mental well-being. Last but not least, the pressure has a considerable impact on interpersonal relationships in the workplace. Therefore, in the following years, prudent and rational employers should increasingly include "the possibility of consulting services the Employee Assistance" among employee benefits to maintain the quality of their employees' lives. As Kazdová stated, "the essence of such professional consulting services is the option to contact the expert whenever is needed - a psychologist, psychotherapist, to entrust him with personal problems and get expert advice. ...Timely expert assistance is of great importance, not only for mental well-being and health of a specific employee, but it also affects his/her job performance and thus brings benefits also the employer." ${ }^{18}$ This service is provided through contractual relationships with partner companies and it is provided to employees on the basis of across the board benefits. A significant fact for employees is that the service is available to them under absolute confidentiality and anonymity (the employer only receives, after a period of time, general recommendations for improving HR processes

\footnotetext{
${ }^{18}$ KAZDOVÁ, A. Zaměstnanci ocení, když jim firma umožní řešit osobní problémy. HRM - Human Resources Management, July - August 2010, p. 22.
} 
and a report on the use of services). Employees can take advantage of consultation with external experts "face to face", via telephone or e-mail. By using this service, many decisions to leave an employer and look for opportunities in other companies can be averted.

The aim of each company should be maintaining such comprehensive portfolio of employee benefits, so that it would fully meet the requirements and preferences of their employees. Employees must not accept employee benefits automatically, routinely and only because they are offered to them. Possible legislative changes and adjustments in terms of providing by employers and drawing by employees will have great influence on the future and the robustness of the provision of benefits.

\section{Conclusion}

In response to the challenges for HRM in the post-crisis period, as defined in the Introduction of this paper, it is important to consider the following questions: Does the perception of human capital change more and more in society? Has humanity reached the beginning of another a new era of "human period" - "the Human Age"? Looking back into the past, we discover significant periods named according to the milestones of that time and according to the technologies (materials) that characterized the given period - whether it is the Stone Age, the Bronze Age or the Iron Age. For example, there are periods named as: the industrial age, the space age, and in recent decades we talk about the information age. The question is, whether the current period is the beginning of a new era - the era of "Human Age." It is very likely that in the following years, all sectors of human activity will be more dependent on human capital that will be the main driving force not only in the private sector. Recently we can more and more hear voices (unfortunately true voices) that in companies, people with required qualifications are increasingly becoming more necessary and more desirable than ever before. At the same time, sighs resound that such workers are often "in short supply" and rare. This situation leads to serious problems associated with filling not only the key job positions in enterprises.

If we accept the name Human Age, or at least the enormously increasing importance of human capital and knowledge of people in work activities, it is clear that companies, in the deepening competitive fight, will be soon forced to target a large part of corporate management just on human resources. Only a strategic and coherent focus on streamlining the methods of the filling job positions; the use of the latest approaches in education, development and planning the careers of employees; their targeted motivation; fair and alternative remuneration can lead to obtaining the competitive advantage of the companies. Thus conceived concept of HRM has significant benefits to the degree of staff turnover, and positively affects also the unemployment rate in individual countries.

The aim of this article was to present the main developments in the field of HRM, which may be significant in further development and operation of companies and, hence, in the development of unemployment in the sub-economies. This objective was fulfilled in four chapters that focused on trends/ challenges of HRM in the HR planning, the filling of job positions, employee training, development and remuneration.

\section{Literature:}

[1] ARMSTRONG, M. Armstrong's Handbook of Human Resource Management Practice. $11^{\text {th }}$ ed., London: Kogan Page, 2009, 1062 p. ISBN 978-0-7494-5242-1. 
[2] ČAPKOVÁ, A., SKALKOVÁ, J. Vybrané nejnovější trendy ve vzdělávání a rozvoji zaměstnanců [online]. Dostupné z:

URL http://hrforum.peoplemanagementforum.cz/cs/i/vybrane-nejnovejsi-trendy-vevzdelavani-a-rozvoji-zamestnancu/, [cit. 2011-07-30].

[3] HRONÍK, F. Změna role HR aneb ř́zení lidí v pohybu. HRM - Human Resources Management, May - June 2010, vol. 6, no. 3, p. 16 - 19. ISSN 1801-4690.

[4] ILO: Zaměstnanost vzroste až v roce 2015. HRM - Human Resources Management, November - December 2010, vol. 6, no. 6, p. 9. ISSN 1801-4690.

[5] JEMALA, L. Souřadnice rozvoje managementu. Moderní řizení, May 2010, vol. 45, no. 5, p. 52 - 53. ISSN 0026-8720.

[6] KAZDOVÁ, A. Časy se mění: Více muziky za méně peněz. HRM - Human Resources Management, November - December 2010, vol. 6, no. 6, p. 2 - 4. ISSN 1801-4690.

[7] KAZDOVÁ, A. Zaměstnanci ocení, když jim firma umožní řešit osobní problémy. HRM - Human Resources Management, July - August 2010, vol. 6, no. 4, p. 22 - 24. ISSN 1801-4690.

[8] KOUBEK, J. Řizeni lidských zdrojů. Základy moderni personalistiky. $3^{\text {rd }}$ ed., Praha : Management Press, 2001, 367 p. ISBN 80-7261-033-3.

[9] LANDA, O. Jakou roli ve strategii dnes hraje HR? HRM - Human Resources Management, May - June 2010, vol. 6, no. 3, p. 12 - 14. ISSN 1801-4690.

[10]PALATA, K. Trendy v odměňování. HRM - Human Resources Management, March April 2011, vol. 7, no. 2, p. 12 - 15. ISSN 1801-4690.

[11]PŘIKRYL, J. Firmy postupují při náboru stále opatrně a jsou důkladnější. HRM - Human Resources Management, January - February 2011, vol. 7, no. 1, p. 60 - 61. ISSN 1801-4690.

[12] SLABÁ, P. Všechno, co jste chtěli vědět o firemnich systémech vzdělávání a báli jste se zeptat... [online]. Dostupné z:

URL http://hrforum.peoplemanagementforum.cz/cs/i/vsechno-co-jste-chteli-vedet-ofiremnich-systemech-vzdelavani-a-bali-jste-se-zeptat/, [cit. 2011-07-25].

Klasifikace JEL: J24, O15

\section{Ing. Petra Janečková}

Doktorandka Katedry společenských věd

Obchodně podnikatelská fakulta v Karviné

Slezská univerzita v Opavě

Univerzitní nám. 1934/3, 73340 Karviná

E-mail: janeckova@opf.slu.cz

\section{Ing. Radim Řihák}

Doktorand Katedry společenských věd

Obchodně podnikatelská fakulta v Karviné

Slezská univerzita v Opavě

Univerzitní nám. 1934/3, 73340 Karviná

E-mail: rihak.r@seznam.cz 